\title{
INTRODUCING ENGLISH TO EARLY CHILDHOOD THROUGH SINGING WITH THE TOTAL PHYSICAL RESPONSE METHOD
}

\author{
Septi Gumiandari ${ }^{1}$ \\ ${ }^{1}$ IAIN Syekh Nurjati Cirebon \\ Email: septigumiandari@gmail.com
}

\begin{abstract}
Introducing English from an early age should be supported by adequate media and infrastructure. Learning should be arranged in such a way as to give birth to learning activities that are important and fun. Therefore, it requires perfect and efficient teaching methods. Research on aims to introduce English by singing to early childhood at al-Hidayah Kindergarten, Greged District, Cirebon. This study uses field research with a qualitative descriptive method. The subjects of this study were the head of kindergarten and teachers. Data obtained through observation, interviews, and documentation. Data were analyzed using several steps: data reduction, data display, conclusion drawing/verification. The process is carried out using several methods such as singing while playing and singing, with movements using learning media. The conclusion is that by using the singing and playing method, early childhood children can easily recognize the vocabulary, and can accidentally add to the vocabulary of the child. This research can be an input for teachers in enriching learning methods for children by adjusting to the characteristics of early childhood who like to move, and feel bored quickly if they just sit on a chair. Selection of the right learning method can affect children's learning motivation and help early childhood understanding of English language learning.
\end{abstract}

Keywords: English, early childhood, singing while playing.

\section{INTRODUCTION}

Given the importance of speaking English because the international language is spoken throughout the world (Santoso, 2014). Therefore it is necessary to instill it in future generations from childhood. Childhood is a magical time, this can be seen when children are born. During this period, the guidance of parents, teachers and the environment has a very important role. Because of that, the most important influence is the influence of the school environment. Here the role of parents is also very influential on the progress of children's language (Liyana \& Kurniawan, 2019). Mothers and other people must also give examples to children using good and correct language. Because the language that is often heard by children will be easily imitated (Samad, 2015). 
In the introduction of English, it is hoped that it will be able to encourage, guide, develop and foster abilities, students and foster positive attitudes towards foreign languages, both receptive and productive. Preschool children's language development is far from perfect. Children's language skills can be instilled in various ways, including singing, listening to songs, reading stories or news, playing guessing words/pictures, and so on (Gunawan \& Yuline, 2014). These skills should be instilled in children from an early age, where they are sensitive to learning so that when they are adults the children are more active and have faster growth and development (Dwiastuty, Anggoro \& Anita, 2016).

Based at the outcomes of studies performed by Lestari \& Kurniati (2019) with the title: "Combination of Totally Physical Response". This studies pursuits to offer facts approximately trainer creativity and innovation in combining the TPR technique and coaching English the usage of through music to make it less complicated for kids to apprehend simple ideas in English. One aspect of development, which needs to be developed in a way is language development because in early childhood, children are at the golden age where children are sensitive to the stimuli given, so that from an early age children are introduced and developed language skills, especially foreign languages. Foreign languages that can be introduced early. Through language, children can communicate with others to express and understand the thoughts and feelings that children speak and other people say in the form of spoken, written, facial expressions, symbolic language, signs, pantomime and art.

Furthermore, the results of research conducted by Astuti (2016) with the title "The Effect of the Total Physical Response Method on the Ability to Listening to English Vocabulary". This look at pursuits to decide the contribution of Total Physical Response to early childhood in listening ability and mastering English vocabulary. Learning English in early childhood must be done in a fun and close manner with the daily activities of children. TPR (general bodily response) fulfills this element. The TPR approach changed into advanced with the aid of using James J Asher. This method develops listening / listening skills, introduces new languages in a visual, contextual way, and involves physical activity and movement.

Furthermore, the outcomes of studies carried out via way of means of Astutik and Aulina (2018) with the title "The Total Physical Response (TPR) Method in Teaching English for Kindergarten Students". This take a look at objectives to research how instructors at TK Aisyiyah five Tanggulangin train English the use of the TPR approach to their students. This studies approach makes use of descriptive qualitative studies methods. There are many aspects 
that affect the development of a child, these aspects make a major contribution to children's development, including motor, cognitive, social, physical, emotional and language development. Dialogue about the progress of language without knowing the language is a view that gives great participation in the development of children. Samad (2015) reported that by using language, children want to be able to develop and grow into adults who can make friends among residents. Especially in early childhood, speaking and speaking skills are desires and are about the essence of the process at school.

From the previous researches above, it is clear that the role of teachers and parents is very important for children's language progress. In order for children to speak properly and correctly, an educator (both teacher and parent) must often invite the child to talk. However, there are critical matters that ought to be taken into consideration with inside the coaching and mastering technique, that's to create a laugh mastering atmosphere, in order that the kid is responsive and now no longer stressed. Therefore, it's far vital to have studies on a bendy mastering technique or via video games to make it appearance extra appealing to the kid. Therefore, the author wants to explain about this study with the intention of introducing English via making a song in early childhood and to discover the technique of coaching and mastering English via making a song in early childhood. So that, this research aims to introduce English by singing to early childhood at al-Hidayah Kindergarten, Greged District, Cirebon. The benefit of this research is that it can be an input for teachers in enriching learning methods for children by adjusting to the characteristics of early childhood who like to move, and feel bored quickly if they just sit on a chair. Selection of the right learning method can affect children's learning motivation and help early childhood understanding of English language learning.

\section{METHOD}

This study uses field research with qualitative descriptive methods in which data collection is carried out directly at the research location. This research has a descriptive formulation characteristic which is shown to analyze and present the actual situation in the research location. The type of data is qualitative (Moleong, 2010). Arifin (2020) stated that this method serves to describe illustrations of the object under study through data or samples that have been collected as they are without analyzing and producing conclusions which apply to the layman. To achieve the expected goals, the form of activity that will be carried out is teaching, namely the introduction of English through singing in early childhood. Activities will be carried 
out using several methods such as singing while playing and singing using movements. The research location is in al-Hidayah Kindergarten, Greged District, Cirebon. Subjects in this study were heads and teachers of al-Hidayah Kindergarten. The object of research in qualitative research is the social situation, which consists of three components, namely place, actor, and activities. Data obtained through observation, interviews, and documentation. Data were analyzed using several steps: data reduction, data display, conclusion drawing/verification (Sugiyono, 2010).

\section{FINDINGS AND DISCUSSION}

The total physically response method (TPR method) is a method that is suitable for teaching English such as vocabulary and short, expressions to early childhood, where learning prioritizes direct activities, which, while teaching English using by song (Widya \& Agustina, 2019). Active learning is like singing together so that the activity creates a pleasant atmosphere so that children learn indirectly. For the pronunciation and intonation of a vocabulary (Shehadeh \& Farrah. 2019).

According to Ekawati (2020), TPR changed into first delivered via way of means of Asher, a professor emeritus of psychology at San José State University after being stimulated via way of means of how children, definitely research their first language, via way of means of responding bodily to speech, first of all thru commands. Asher initiated TPR when he wondered why so many people had difficulty learning a second language but hardly anyone had difficulty learning their first language (Harfida \& Dewi, 2019). Then Asher (as quoted from Astutik \& Aulina, 2017) observes the characteristics of successful language learners, namely: Good language learners achieve fluency more quickly when they are involved in situations where the meaning of spoken language is immediately felt and understood; They often begin their language learning by seeing the influence of language on actions and demonstrate their understanding by performing well-commanded language tasks; They can focus on the overall meaning rather than grammar and progress more quickly when the language of instruction remains there every day, and they progress quickly when content involving English is clearly useful for use outside the classroom (Saryati, 2017).

Learning English is extra amusing for early life while it includes direct activities, which can be associated with bodily pastime (bodily), and motion (motion) (Sandhy, 2017).. In this 
method, Asher stated that giving stimulation this is achieved again and again will give a boost to the affiliation of associated recollections and it's going to make it less complicated to remember (recalling). This pastime of remembering is achieved verbally, with motor pastime (motor activity). Furthermore, Asher additionally concluded that during mastering in early life the emotional issue additionally has a totally huge role; with inside the language mastering system that suggests motion and making a song in video games can limit the strain of mastering kid's language. He believes that pleasure in children (high-quality mood) can have a high-quality effect on kid's language mastering (Zahro, I \& Pertiwi, EP, 2020).

A good teacher must have the initiative in creating a learning atmosphere with the aim of helping children understand a lesson. The excellent teacher should introduce from an early age by adequate media and infrastructure (Asilestari, 2016), so that the learning activities should be arranged in such a way as to give birth to learning activities that are important and fun (Mustofa, Wekke \& Hasym, 2019). One of which is by varying the teaching techniques and teaching media such as the TPR method and teaching English using by song. The TPR method and teaching English using by song can create a pleasant learning atmosphere in the classroom (Lestari, R H; Kurniati, E, 2019).

The concept of teaching foreign languages cannot be separated from the concept of learning itself. The better understanding of the nature of child development has resulted in a view of constructiveness in learning. Regarding language learning, the most important thing that must be understood is that language learning is an acquisition process with the aim of achieving communication skills (Widiputera, 2004). Second language theory shows that a child learns because of a need for it, and they can fulfill this through language learning. The theory also says that language skills develop gradually from easy to more complex ones (Yamin. M, 2017).

Learning English vocabulary is basic learning which is very possible for children who are starting education, especially AUD education. Vocabulary learning will be equivalent to the process of children learning to communicate (Syahputra, 2015). By utilizing methods such as: singing (Ratmaningsih, 2014), learning English with basic vocabulary material, it will be more fully embedded in preparing for proficiency in English, at the later education level.

Teaching English via way of means of the usage of music is one manner of coaching English via way of means of the usage of music because the medium. Given that English is an overseas language in Indonesia, of route the mastering procedure calls for the perfect and 
powerful approach. The fulfillment of mastering English in early adolescence is strongly inspired via way of means of the capacity of a trainer to offer an exciting and amusing coaching and mastering procedure for children (Yamin, M, 2017).

The results of the observations show that al-Hidayah Kamarang Kindergarten teachers use aspects of the TPR method to their students when teaching English vocabulary in the classroom. Not simplest at some stage in the studying system with inside the classroom, however additionally while the trainer makes use of the TPR technique while interacting with college students outdoor the classroom. From this studies additionally, its miles recognized that after the trainer offers instructions or instructions with inside the utility of the TPR technique, college student's now no longer simplest reply with bodily or non-verbal moves however additionally with speech responses.

The activity of introducing English to early childhood through singing was carried out at al-Hidayah Kindergarten, Greged District, Cirebon. The number of participants involved in this activity were 2 teachers of Kindergarten al-Hidayah and 10 children of Kindergarten al-Hidayah in class B. The form of activity carried out is teaching to introduce English through singing.

The results of preliminary observations made at al-Hidayah Kindergarten show that all this time learning has used the singing method and the memorization method. Regular question and answer in English has been carried out before the lesson is carried out, such as;

Teacher: "Assalamulaikum students,"

Student: "Waalaikum salam wr.wb"

Teacher: "Morning, class"

Student: "morning mrs."

Teacher: "How are you today?"

Student: "I'm fine, and you?"

Teacher: "I'm Fine, too"

The first songs performed for the introduction of English through chants were as follows:

\section{Good Morning}

Good morning everybody how are you? $(2 x)$

Good morning to you $2 x$

Good Morning everybody how are you? 
Then the teacher explains the meaning of each word again. As the saying good morning (selamat pagi), everybody (semuanya) and how are you (bagaimana kabarmu?). After that, hold with the making a song technique the use of movements. This technique also can introduce individuals of the frame via way of means of making a song the kid's music Head Shoulders Knees and Toes. So, at the same time as announcing the lyrics invite the kid to factor to their limbs, particularly the head, shoulders, knees and feet. Including eyes, ears, mouth and nose.

Head, shoulders, knees and toes, knees and toes $(2 x)$

And eyes and ears and mouth and nose

Head, shoulders, knees and toes, knees and toes

March (3x). Let us all march

March (3x). Get your body charge!

Head, shoulders, knees and toes, knees and toes $(2 x)$

And eyes and ears and mouth and nose

Head, shoulders, knees and toes, knees and toes

Jump (3x). Let's all jump!

Through this song, kids are delivered to and understand English vocabulary associated with frame parts, which includes head (kepala), shoulders (pundak), knees (lutut), toes (jari kaki), eyes (mata), ears (telinga), mouth (mulut) and nose (hidung). This chant is conveyed with the aid of using motion of the frame and limbs. While singing, the trainer and kids' factor to limbs that fit the English vocabulary being sung.

The activity of introducing English the use of this approach is predicted to take location constantly and gradually. Especially with getting to know in an thrilling way, in order that youngsters may be glad and cheerful, they may be capable of maximize their 2nd language getting to know capacity in order that Indonesian youngsters will seem with inside the destiny who're capin a position and fluent in English.

\section{CONCLUSIONS}

The study reveals that introducing English to early childhood through singing with the total physical response method can make preschoolers easy to digest and pronounce English vocabulary. In addition, the children's enthusiasm was very high when the teacher delivered material and sang songs in English. This research can be an input for teachers in enriching learning methods for children by adjusting to the characteristics of early childhood who like to 
move, and feel bored quickly if they just sit on a chair. Selection of the right learning method can affect children's learning motivation and help early childhood understanding of English language learning. Therefore, it is advisable for educators (teachers/parents) who have preschool-aged children to introduce foreign languages by using fun methods such as through songs.

\section{REFERENCES}

Arifin, Z. (2020). Metodologi penelitian pendidikan. Jurnal Al-Hikmah, 1(1).

Asilestari, P. (2016). Komputer Interaktif sebagai Media Pengejar Bahasa Inggris pada Anak Usia Dini. Jurnal PG PAUD STKIP PTT, 2(1), 29-45.

Astuti, W. (2016). Pengaruh Metode Total Physical Response Terhadap Kemampuan Menyimak Kosakata Bahasa Inggris. The 3rd University Research Colloquium.

Astutik, Y., \& Aulina, C. N. (2017). Metode Total Physical Response (TPR) Pada Pengajaran Bahasa Inggris Siswa Taman Kanak-kanak. Metode Total Physical Response (TPR) Pada Pengajaran Bahasa Inggris Siswa Taman Kanak-Kanak, 17(2), 9-23.

Astutik, Y., \& Aulina, C. N. (2017). Metode Total Physical Response (TPR) Pada Pengajaran Bahasa Inggris Siswa Taman Kanak-kanak. Metode Total Physical Response (TPR) Pada Pengajaran Bahasa Inggris Siswa Taman Kanak-Kanak, 17(2), 9-23.

Dwiastuty, N., Anggoro, D., \& Anita, T. (2016). Pembelajaran Bahasa Inggris Melalui Metode Total Physical Response. Faktor Jurnal Ilmiah Kependidikan, 3(1), 29-34.

Ekawati, A. D. (2020). Penerapan Metode Total Physical Response (TPR) dalam Pengajaran Bahasa Inggris di TK. E-Dimas: Jurnal Pengabdian kepada Masyarakat, 11(1), 71-73.

Gunawan, V., \& Yuline, H. (2014). Peningkatan Kemampuan Pengucapan Bahasa Inggris Melalui Metode Bernyanyi pada Anak Usia 5-6 Tahun. Jurnal Pendidikan dan Pembelajaran, 3(8).

Harfida, R. \& Dewi, N.K. (2019). Metode TPR (Total Physical Response) Dalam Pembelajaran Bahasa Inggris Pada Anak Usia Dini. Prosiding Seminar Nasional Pendidikan Dan Pembelajaran.

Lestari, R. H., \& Kurniati, E. (2019). Perpaduan Totally Physical Response Method (Tpr Method) Dengan Lagu Dalam Mengembangkan Kemampuan Bahasa Inggris Anak Usia Dini. Tunas Siliwangi: Jurnal Program Studi Pendidikan Guru PAUD STKIP Siliwangi Bandung, 5(1), 16-22. 
Liyana, A. \& Kurniawan, M. (2019). Speaking Pyramid Sebagai Media Pembelajaran Kosa Kata Bahasa Inggris Anak Usia 5-6 Tahun. Jurnal Obsesi: Jurnal Pendidikan Anak Usia Dini, $3(1), 225-232$.

Moleong, L. J. (2010). Metode Penelitian Kuantitatif, Kualitatif Dan R \& D, Bandung: Alfabeta.

Mustofa, D., Wekke I.S., \& Hasym, R. (2019). Penerapan Joyfull Dalam Pembelajaran Bahasa Inggris (Tinjauan Psikolinguistik). Jurnal Bahasa Dan Linguistik, 8(2), 110-118.

Ratmaningsih, N.M. (2014). Pengembangan Model Pembelajaran Bahasa Inggris Induktif Berbasis Lagu Kreasi. Jurnal Ilmu Pendidikan, 20(1), 47-58.

Samad, F. T. (2015). Strategi Pembelajaran Bahasa Yang Menyenangkan Untuk Anak Usia Dini. Cahaya Paud, 2(1), 47-57.

Sandhy, N. (2017). Metode Total Physical Response (TPR) Terhadap Penguasaan Kosakata Anak Tunarungu TK/Kb. Jurnal Pedidikan Khusus. 9(3), 1-14.

Santoso, I. (2014). Pembelajaran Bahasa Asing Di Indonesia: Antara Globalisasi Dan Hegemoni. Bahasa Dan Sastra, 14(1), 1-11.

Saryati, I. (2017). Efektivitas Penggunaan Metode Total Physical Response Dalam Meningkatkan Penguasaan Vocabulary Bahasa Inggris Pada Siswa Sekolah Dasar. Jurnal Pendidikan Universitas Garut. 11(1), 38-49.

Shabaneh, Y., \& Farrah, M. (2019). The effect of games on vocabulary retention. Indonesian Journal of Learning and Instruction, 2(01).

Sugiyono (2010). Metode Penelitian Pendidikan Pendekatan Kuantitatif, Kualitatif dan R \& D, Bandung: Alfabeta

Syahputra, I. (2015). Strategi Pembelajaran Bahasa Inggris Sebagai Bahasa Asing dalam meningkatkan kemampuan berbahasa siswa. Kutubkhanah, 17(1), 127-145.

Widiputera, F. (2004). Model - Model Pembelajaran Bahasa Inggris Yang Inovatif.

Widya \& Agustina, E. (2019). Peningkatan Penguasaan Kosakata Dengan Metode Total Physical Response (TPR). Simposium Nasional Ilmiah Dengan Tema: (Peningkatan Kualitas Publikasi Ilmiah Melalui Riset Dan Pengabdian Kepada Masyarakat),1187-1194.

Yamin, M. (2017). Metode Pembelajaran Bahasa Inggris Di Tingkat Dasar. Jurnal Pesona Dasar, 1(2), 82-97.

Zahro, I \& Pertiwi, Ep. (2020). Implementasi Metode Total Physical Response Method (TPR) Untuk Meningkatkan Kosakata Bahasa Inggris Pada Anak Usia Dini. Inovasi, 22(12), 3036. 